\title{
電気二重層キャパシタの技術動向
}

\author{
古 賀 淳 史* \\ 日本ケミコン株式会社＼cjkstart研究開発本部＼cjkstart第三製品開発部＼cjkstart恶993-8511山形県長井市幸町 1-1 \\ (2019年 7 月 31 日受付；2019年 8 月 6 日掲載決定)
}

\section{Technology Trend of Electric Double Layer Capacitor}

\author{
Atsushi KogA* \\ Nippon Chemi-Con Corporation, 1-1, Saiwai-cho, Nagai, Yamagata 993-8511
}

(Received July 31, 2019 ; Accepted August 6, 2019)

\begin{abstract}
Electric double layer capacitor is used for various applications because of its unique characteristics, such as high reliability, less environmentally-load and high rate capability. The present paper describes a basic principle, constitution, characteristics, applications and future prospects of electric double layer capacitor.
\end{abstract}

KEYWORDS : electric double layer capacitor, DLCAP ${ }^{\mathrm{TM}}$, Nippon Chemi-Con

\section{1.は じめ に}

近年地球温暖化などの環境問題，東日本大震災及び原 発事故に伴う電力供給問題や資源枯渇問題を受けてエネ ルギーの有効活用, 省エネルギー化の動きが活発になっ ており,これらの動きに相まって蓄電デバイスの重要性 が高まっている。その中でも電気二重層キャパシタは高 い信頼性, 低環境負荷, 入出力特性の高さなどの特徴を 持ち, 様々なアプリケーションに適用されている。本稿 では電気二重層キャパシタの基本原理, 構成や特徵, 応 用事例，日本ケミコンでの取り組みについて述べる。

\section{2. 電気二重層キャパシタ概要}

\section{1 電気二重層キャパシタの動作原理}

電気二重層キャパシタは電極表面と電解液との界面に 生じる電気二重層を利用し, 電荷を蓄える蓄電デバイス である。充放電時に正極表面にマイナスイオンが，負極 表面にプラスイオンが物理的に吸脱着する（Fig. 1)。そ の際に電極と電解質イオンとの間に化学反応を伴わない ため, 充放電速度が速く, かつ繰り返し充放電による劣 化が少なく長寿命である特徴をもつ。またそのような蓄

\footnotetext{
*E-mail : koga@y.nippon.chemi-con.co.jp
}

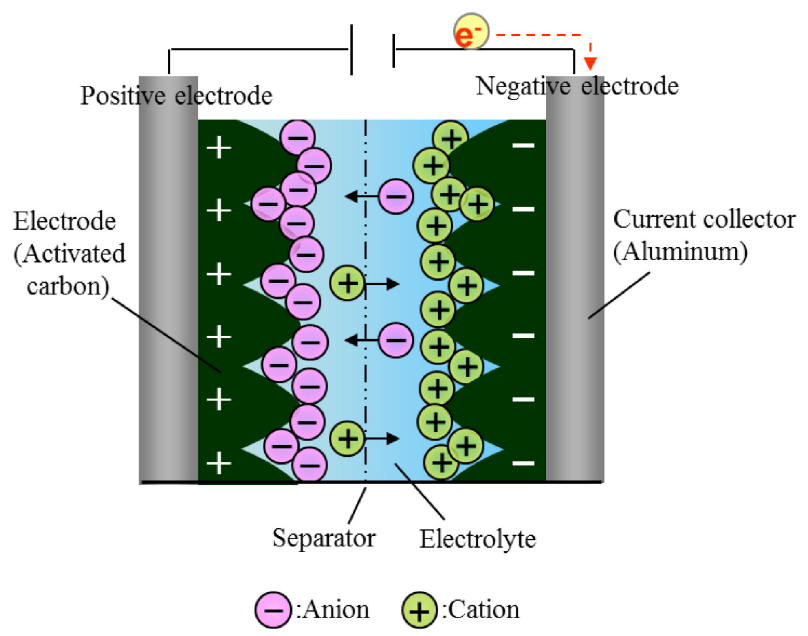

Fig. 1. (color online). Illustration of electric double layer capacitor.

電原理をもつため, 定電流での充放電時には電圧が直線 的に変動する挙動を示し，電圧と蓄電量が比例する (Fig. 2)。

\section{2 電気二重層キャパシタの基本構成と形状}

電気二重層キャパシタの基本的な構成は, 正負電極が セパレーターを介して対向し，電極，セパレーターには 電解液が含まれている (Fig. 3)。これら電極素子には電 


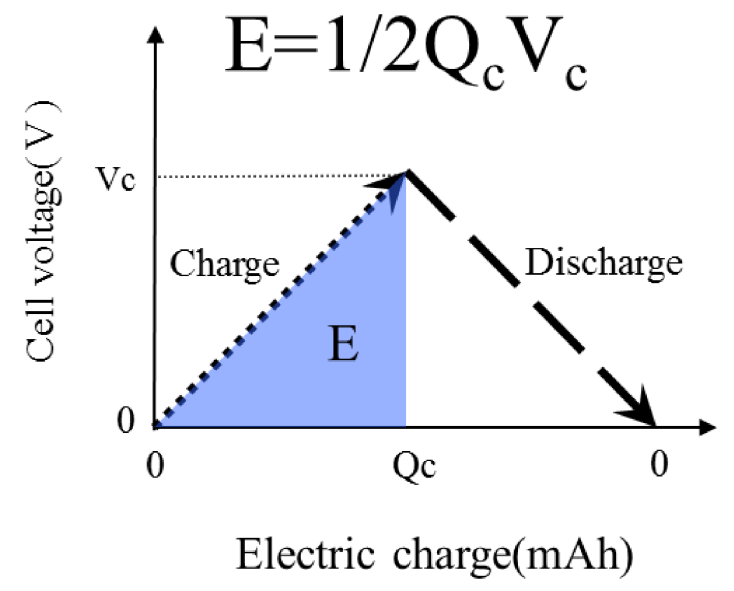

Fig. 2. (color online). Charge-Discharge curves of EDLC.

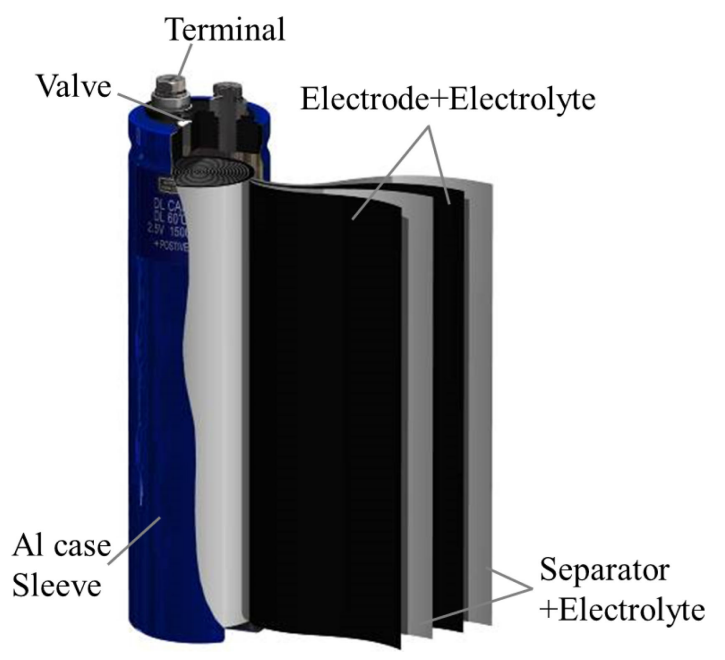

Fig. 3. (color online). Configuration of cylindrical type.

極を巻回させた円筒型，短冊状の電極を積層させた積層 型がある。また電極素子は外装により外気と遮断され密 閉される。外装材には金属缶 (円筒缶, 角型缶, コイン タイプ)，ラミネートフィルムなどがある（Fig. 4）。

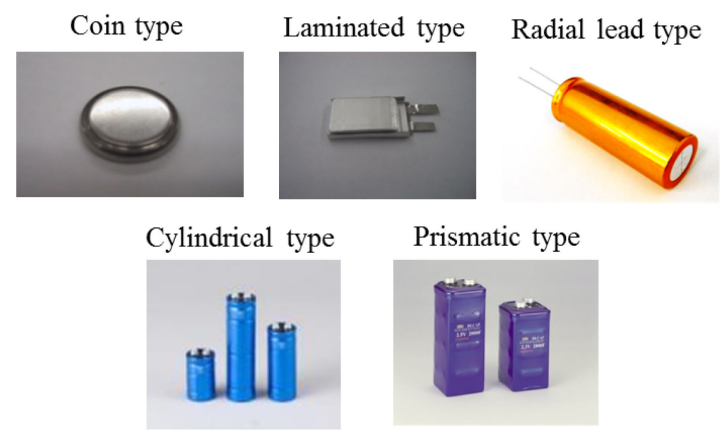

Fig. 4. (color online). Configuration of EDLC cells.

\section{3 電気二重層キャパシタの構成材料}

(1) 電極材料

電気二重層に蓄えられる電荷量 Q は式（1）によっ て表される。

$$
\mathrm{Q}=\mathrm{CV}
$$

電荷量は静電容量 C と印加電圧 V に比例する。また静 電容量は式（2）によって表される。

$$
\mathrm{C}=\varepsilon \mathrm{S} / \mathrm{d}
$$

静電容量は誘電体の誘電率 $\varepsilon$ と電極表面積 $S$ に比例し電 極間距離 $\mathrm{d}$ （ここでは電気二重層厚み）に反比例する。 このことから電気二重層キャパシタの電極材料は表面積 が大きいことが求められ, 実際には活性炭（表面積：約 $2000 \mathrm{~m}^{2} / \mathrm{g}$ ) が電極材料として用いられる。活性炭の原 材料としては梆子がら, フェノール樹脂, 石炭などの炭 素前駆体を炭化したものが用いられる。これらの炭化物 を高温で水蒸気やアルカリと反応させて微細孔をつくる ことにより非常に大きな比表面積を持たせる。これらの 微細孔の大きさ, 量は電気二重層キャパシタの容量, 内 部抵抗, 温度特性を決定する重要な因子であるため, 電 気二重層キャパシタの用途によりこれらの值を設計する 必要がある。これらの活性炭を主材料とし, 導電性付与 のためのカーボン系導電助剤やポリテトラフルオロエチ レン, ポリフッ化ビニリデン, エラストマー系などの接 着剂を混合しアルミニウム箔に担持させたものを正負極 電極として用いる。

(2) セパレーター

電気二重層キャパシタのセパレーターの役割は正負極 間の絶縁, 電解液の保持である。材質としてはポリプロ ピレン等の樹脂系やセルロース等の紙系のものが用いら れる。一般的にはセル製造時の乾燥条件などを考慮して 紙系セパレーターが用いられることが多い。またセパレ ーターの厚みや密度は電気二重層キャパシタの容量, 抵 抗に影響を及ぼすため，これらの值を最適化し，用途に 応じて使用している。

（3）電解液

電気二重層キャパシタの電解液には, 溶媒に電解質を 溶解させたものが用いられ，溶媒の種類により水系，非 水系とに分けられる。水系電解液の代表例としては硫酸 水溶液があげられる。硫酸水溶液は電気伝導率が高いた め電気二重層キャパシタの内部抵抗を低くできる。ただ し水の電気分解電圧が低いためセルとしての定格電圧が 低くなってしまう（約 1 V）デメリットがある。一方非 水系電解液の代表例としては四級アンモニウム塩をプロ ピレンカーボネート等の有機溶媒に溶解したものがあげ 
られる。非水系電解液は電気伝導率が低いため, 水系と 比較すると内部抵抗が高くなるが, 電気分解電圧は高く なるため，七ルの定格電圧を高くできる（2.5～3.0 V 程 度）メリットがある。電気二重層キャパシタに蓄えられ るエネルギーは電圧の 2 乗に比例するため, 高エネルギ 一が要求される用途では非水系電解液が用いられること が多い。日本ケミコンでは様々なサイズの電気二重層キ ヤパシタ（DLCAP $\left.{ }^{\mathrm{TM}}\right)$ を製造しているが，いずれも非 水系電解液を用いている。

\section{3. 電気二重層キャパシタの応用事例}

$1 ， 2$ 節で述べた通り，電気二重層キャパシタは高い 信頼性, 低環境負荷, 入出力特性の高さ, 優れた寿命性 能などの特徵を持っている。今節ではこのような特徴を 活かした電気二重層キャパシタの応用事例について述べ る。

\section{1 電力貯蔵}

太陽光発電や風力発電などの再生可能エネルギーは発 電時に $\mathrm{CO}_{2}$ を発生させず, 資源枯渴の問題もないこと から新しいエネルギーとして注目されている。しかしな がらこれらのエネルギーは天候や時間带により出力が大 きく変動してしまう課題があり, 蓄電装置と組み合わせ て使用されることが多い。電気二重層キャパシタは微弱 な電流でも充電可能で, 低温特性にも優れているため寒 冷地でも設置可能であり, 再生可能エネルギーとの相性 が良い。また長寿命であるため部品交換が困難な用途や 設置場所において, 交換頻度の低減やメンテナンスフリ 一を目的に採用されている。具体的には自発光式道路 鋲 ${ }^{1)}$ や太陽光発電式 LED 街路灯, 交通情報収集端末など の採用例がある。また近年太陽光発電マイクログリッド システムの蓄電媒体として電気二重層キャパシ夕を採用 する試みもでてきている21。

\section{2 エネルギー回生}

エネルギー回生システムは車両などが減速する際に生 じるエネルギーを蓄電デバイスに回収し，再利用するシ ステムである。従来熱エネルギーとして廃裹していたエ ネルギーを再利用することにより燃費向上効果が見込め る。2012 年に発売された ATENZA（マッダ株式会社） に世界初となる電気二重層キャパシタを採用した自動車 用減速エネルギー回生システム “i-ELOOP”が搭載され た。このシステムは減速時に発生する回生エネルギーを 電気エネルギーとして電気二重層キャパシタに蓄電し, 蓄えられたエネルギーは，DC/DCコンバーターを介し て，アイドリングストップ時の電装系電力として利用さ れる。このことにより回生エネルギー分の発電燃料を削 減することが可能となり『加減速が頻繁にある状況では
$10 \%$ 程度の燃費向上が見込まれる。』とされている。

このシステムの蓄電デバイスとして電気二重層キャパ シタが採用された主な理由は以下の通りである。

（1）入出力特性が高く，大電流の充放電が可能

(2) サイクル寿命が長く，大電流充放電での劣化が少 ない

（3）適応環境温度範囲が広く, 高温雲囲気での使用が 可能

（4）環境負荷物質を含まず，安全性が高い

まず（1）に関して，減速の限られた時間内に多くのエ ネルギーを蓄えるには，大電流充電に対応できる高い充 電受入れ性能（低内部抵抗）が必要である。電気二重層 キャパシ夕は鉛蓄電池の 10 倍以上の充電受入性能を有 し『i-ELOOP は可変電圧オルタネータとキャパシタを採 用することで, 従来比約 3 倍の減速エネルギーを回生す る能力を得た』4)とされている。また大電流を扱う電気 二重層キャパシタモジュールは, 配線抵抗による電圧ド ロップを避けるため, オルタネータ直近のエンジンルー ム内に搭載されている。エンジンルーム内はアイドリン グ停車時等に $80^{\circ} \mathrm{C}$ 以上の高温環境となる場合があり （2）（3）の特性が求められる。高温環境に対応していな い二次電池では別途冷却装置の実装が必要となり, モジ ユールの大型化，コストアップが避けられないため, 電 気二重層キャパシタが採用された。また電気二重層キャ パシタは $\mathrm{Ni}, \mathrm{Pb}$ 等の重金属, 及び有害物質をほとんど 含まず安全性が高いことに加え，鉛蓄電池のようにモジ ユール回収が必須ではないため, 回収コスト削減のメリ ットもある。

エネルギー回生用途では上記で紹介した自動車以外に もエレベーター, クレーン，電車，フォークリフト，建 設重機など様々な用途で電気二重層キャパシタが採用さ れ，燃費向上の一翼を担っている。

\section{3 電力の安定化}

電力系統への落雷等により瞬間的に電圧が低下する現 象 “瞬低” は工場の製造ライン停止や制御機器の誤作動 を引き起こす。特に半導体や液晶パネル等を製造する高 度な製造装置は瞬低の影響を受けやすく，それらの製造 工場には瞬低対策として瞬低補償装置を導入するケース がある。瞬低補償装置は瞬低の際に蓄電デバイスより電 力を出力し電圧低下を防ぐ装置で，蓄電デバイスには鉛 蓄電池などの二次電池や電解コンデンサ, 電気二重層キ ヤパシタが用いられている。電気二重層キャパシタは入 出力特性が高いため瞬低用途に適しており，また充放電 による劣化も少ないためメンテナンス費用を抑えられる 等のメリットがある。 


\section{4 バックアップ電源}

近年自動車の電動化が急速に進んでいる。電気自動車 はもちろんのことエンジン車においてもハンドル, ブレ ーキなどあらゆる機器が電気で制御され始めている。そ の一方で，事故や故障などによって鉛バッテリーやリチ ウムイオン電池などからの電力供給が断たれた場合, こ れらの機器は制御不能に陥ってしまう。このような非常 事態に備え自動車にはバックアップ電源が備えられてい る車種もある。これらのバックアップ電源には非常時の 確実な動作が求められるため, 長期信頼性, あらゆる温 度環境で動作できることが必須であり, これらの特徴を 持った電気二重層キャパシタが採用されている。

バックアップ電源用途では上記で紹介した自動車用途 以外にも災害対策用自動販売機, 送電線故障監視装置な どで電気二重層キャパシタが採用されている。

\section{4. 日本ケミコンにおける取り組み}

日本ケミコンでは電気二重層キャパシタ “DLCAP ${ }^{\mathrm{TM}}$ ” を 2003 年に量産開始して以来, 製品ラインアップの拡 充, 性能改善のための研究開発を継続的に行ってきた。 そのなかで 2012 年に上市した DXE シリーズは従来シリ ーズより内部抵抗を半分以下と大幅に低減し，また耐熱 性, 耐振動性も向上させたことにより, 車載用途に採用 され電気二重層キャパシタの生産数を飛躍的に伸ばすき
つかけとなった。また DXE シリーズでの技術的ブレイ クスルーを基礎として更なる性能改善した製品も上市し ている。2015 年には耐熱性能を改善した（従来 $70^{\circ} \mathrm{C} \rightarrow 85^{\circ} \mathrm{C} ） \mathrm{DXG}$ シリーズを，2019 年には耐電圧を向 上させた（従来 $2.5 \mathrm{~V} \rightarrow 2.8 \mathrm{~V} ）$ DXF シリーズをそれぞれ 上市した。また 2018 年には日本ケミコンとしては初の 小型リードタイプ DKA シリーズを上市し，ラインアッ プの拡充を行ってきた。現在も更なる性能改善, ライン アップ拡充を目指し, 研究開発を継続して行っている。

日本ケミコンは『環境と人にやさしい技術への貢献』 を企業理念として事業活動を行ってきた。今後も電気二 重層キャパシタの研究開発, 製造を通じ, 環境と人にや さしい技術への貢献を果たしていきたい。

\section{文献}

1) 西野 敦, 直井勝彦: “大容量キャパシタ技術と材料 II” (シーエムシー出版, 2003).

2) NEDO ホームページ ニュースリリース (2010).

3) 高橋正好, 藤田弘輝, 鈴木正悟, 西田史彦: マツダ技 報 減速エネルギー回生システム“i-ELOOP”のデ バイス開発(2012).

4) 小谷和也, 水落洋行, 久米章友, 湯原将光, 高木 宏, 中上信宏, 春名亮二, 田村和寛他：マツダ技報 減 速エネルギー回生システム “i-ELOOP” 制御技術の 開発 (2012). 